\title{
PENGARUH MOTIVASI BELAJAR DAN KESIAPAN BELAJAR TERHADAP HASIL BELAJAR SISWA MATA PELAJARAN SEJARAH KELAS XI-IIS SMA NEGERI 1 PRAJEKAN SEMESTER GANJIL TAHUN PELAJARAN 2015/2016
}

\author{
Wiji Hartono \\ Dyah Ayu Puspitaningrum
}

\begin{abstract}
Abstrak: Dalam proses pendidikan titik beratnya terletak pada pihak anak didik yaitu akan terjadi proses belajar yang merupakan interaksi dengan pengalaman-pengalamannya. Belajar mengakibatkan terjadinya perubahan pada diri orang yang belajar. Perubahan tersebut bersifat integral, artinya perubahan dalam aspek kognitif, afektif, dan psikomotor. Menurut teori, aspek kognitif dapat dipengaruhi oleh kesiapan belajar siswa. Kondisi siswa yang siap menerima pelajaran dari guru, akan berusaha merespon atas pertanyaanpertanyaan yang telah diberikan oleh guru. Penelitian ini bertujuan untuk mengetahui apakah ada pengaruh motivasi intrinsik, motivasi ekstrinsik dan kesiapan belajar siswa terhadap hasil belajar siswa. Penelitian ini merupakan penelitian kuantitatif. Metode pengumpulan data adalah kuisioner, tes, dan dokumentasi. Subjek penelitian ini adalah siswa kelas XI IIS dengan jumlah populasi 65 siswa. Analisis data meliputi korelasi dan analisis varian untuk semua variabel. Uji hipotesis untuk mengetahui pengaruh motivasi intrinsik, motivasi ekstrinsik dan kesiapan belajar siswa terhadap hasil belajar siswa dengan hasil $F_{\text {hitung }}=14,241, F_{\text {tabel }}=3,94$ pada $\alpha=0,05$. Ternyata $F_{\text {hitung }}$ $=14,241>F_{\text {tabel }}=3,94$. Untuk $R$ square didapatkan 41,189\% maka disimpulkan bahwa ada pengaruh motivasi intrinsik, motivasi ekstrinsik dan kesiapan belajar siswa terhadap hasil belajar siswa dengan sumbangan efektif sebesar $41,189 \%$. Sumbangan Efektif (SE) prediktor $\left(\mathrm{X}_{1}\right)$ motivasi intrinsik terhadap kriterium (Y) hasil belajar siswa 9,381\%, Sumbangan Efektif (SE) prediktor $\left(\mathrm{X}_{2}\right)$ motivasi ekstrinsik terhadap kriterium $(\mathrm{Y})$ hasil belajar siswa 0,830\%, Sumbangan Efektif prediktor $\left(\mathrm{X}_{3}\right)$ kesiapan belajar siswa terhadap kriterium (Y) hasil belajar siswa 30,978\% ini menunjukan bahwa kesiapan belajar siswa lebih berpengaruh terhadap hasil belajar siswa dibanding motivasi belajar. Dengan melihat hasil data yang telah dipaparkan sebelumnya, maka dapat disimpulkan bahwa "Ada pengaruh positif antara motivasi belajar dan kesiapan belajar terhadap hasil belajar siswa pada pelajaran sejarah kelas XI IIS di SMA Negeri 1 Prajekan semester ganjil tahun pelajaran 2015/2016.
\end{abstract}

Kata Kunci : Motivasi Intrinsik, Motivasi Ekstrinsik, Kesiapan Belajar, Hasil Belajar

\begin{abstract}
In the educational process the emphasis lies on the part of students that will be a process of learning which the interaction with experiences. Learning resulted in a change in those who learn. Such changes are integral, meaning that changes in cognitive, affective, and psychomotor. According to the theory, the cognitive aspects can be influenced by students' learning readiness. Conditions of students who are ready to receive lessons from teachers, will try to respond to the questions that have been given by the teacher. This study aims to determine whether there is influence intrinsic motivation, extrinsic motivation and readiness to learn students' learning outcomes of students. This research is quantitative. Methods of data collection
\end{abstract}


were questionnaires, tests, and documentation. The subjects were students of class XI IIS with a population of 65 students. Data analysis includes the correlation and analysis of variance fatherly all variables. Hypothesis test to determine the effect of intrinsic motivation, extrinsic motivation and readiness to learn students' learning outcomes of students with the results of $F=14.241$, $F$ table $=3.94$ at $\alpha=0.05$. Turns of $F=14.241>F$ table $=3.94$. For $R$ Square obtained $41.189 \%$, we conclude that there is the influence of intrinsic motivation, extrinsic motivation and readiness to learn students' learning outcomes of students with the effective contribution of $41.189 \%$. Effective contribution (SE) predictor (XI) intrinsic motivation to criterion $(Y)$ student learning outcomes 9.381\%, Effective Contribution (SE) Predictor (X2) extrinsic motivation to criterion ( $Y$ ) $0.830 \%$ student learning outcomes, Contribution Effective Predictor (X3) student learning readiness to criterion (Y) $30.978 \%$ of student learning outcomes of this study indicate that the readiness of students more influence on student learning outcomes than the motivation to learn. By looking at the results of the data which has been described previously, it can be concluded that "There is a positive influence between learning motivation and learning readiness of the learning outcomes of students in eleventh grade history lesson IIS in SMA 1 Prajekan semester of the school year 2015/2016

Keywords: Intrinsic Motivation, Extrinsic Motivation, Readiness Learning, Learning Outcomes

\section{PENDAHULUAN}

\section{Latar Belakang}

Pendidikan merupakan proses yang dapat mengubah obyeknya. Pendidikan bersifat dinamis, melalui pendidikan kita dapat mempertahankan atau mengembangkan nilai-nilai yang kita kehendaki sesuai dengan usaha-usaha pengembangan manusia seutuhnya. Melalui pendidikan sebagai suatu sistem kita dapat memiliki tata kehidupan masyarakat yang kita kehendaki.

Dalam proses pendidikan titik beratnya terletak pada pihak anak didik yaitu akan terjadi proses belajar yang merupakan interaksi dengan pengalamanpengalamannya. Belajar mengakibatkan terjadinya perubahan pada diri orang yang belajar. Perubahan tersebut bersifat integral, artinya perubahan dalam aspek kognitif, afektif, dan psikomotor. Menurut teori, aspek kognitif dapat dipengaruhi oleh kesiapan belajar siswa. Kondisi siswa yang siap menerima pelajaran dari guru, akan berusaha merespon atas pertanyaanpertanyaan yang telah diberikan oleh guru.
Untuk dapat memberi jawaban yang benar tentunya siswa harus mempunyai pengetahuan dengan cara membaca dan mempelajarai materi yang akan diajarkan oleh guru. Dalam mempelajari materi tentunya siswa harus mempunyai buku pelajaran dapat berupa buku paket dari sekolah maupun buku diktat lain yang masih relevan digunakan sebagai acuan untuk belajar. Kondisi siswa yang sehat akan lebih mudah untuk menerima pelajaran dari guru. Dengan adanya kesiapan belajar, siswa akan termotivasi untuk mengoptimalkan hasil belajarnya.

Menurut Wulyo (dalam Nurseto 2010:24) secara sederhana motivasi dapat diartikan sebagai dorongan. Secara teknis istilah motivasi dalam psikologi diartikan sebagai berikut: seluruh proses gerakan, termasuk situasi yang mendorong timbulnya kekuatan pada diri individu; sikap yang dipengaruhi untuk pencapaian suatu tujuan. Motivasi adalah dorongan yang menyebabkan terjadinya suatu perbuatan guna mencapai suatu tujuan. Yang dimaksud motivasi dalam penelitian ini adalah motivasi belajar siswa, yaitu dorongan atau 
kemauan siswa untuk melakukan aktivitas belajar agar prestasi belajar dapat dicapai.

Ciri-ciri motivasi belajar menurut Sardiman (2009:83) yaitu tekun menghadapi tugas, ulet menghadapi kesulitan, menunjukkan minat terhadap bermacammacam masalah, lebih senang bekerja mandiri, cepat bosan pada tugas-tugas yang rutin, dapat mempertahankan pendapatnya, tidak mudah melepaskan hal yang diyakini, senang memecahkan masalah.

Menurut pengamatan di lapangan dan informasi dari guru kelas masih banyak siswa yang mengalami kesulitan belajar, terlihat dari adanya siswa-siswa yang enggan belajar dan tidak bersemangat dalam menerima pelajaran dikelas, siswa pun yang belum aktif dalam mengerjakan soal latihan yang diberikan, sehingga hasil belajarnya pun menjadi kurang memuaskan. padahal selama ini sudah ada fasilitas-fasilitas sekolah yang diberikan untuk mendukung sarana prasarana demi kelancaran dalam proses pembelajaran. Hal itulah yang menjadi permasalahan peneliti, sehingga peneliti ingin mengetahui lebih jauh tentang pengaruh motivasi belajar dan kesiapan belajar terhadap hasil belajar siswa mata pelajaran sejarah kelas XI IIS di SMA Negeri 1 Prajekan tahun pelajaran 2015/2016.

\section{Rumusan Masalah}

Berdasarkan latar belakang masalah diatas, maka peneliti merumuskan masalah sebagai berikut:

\section{a. Mayor}

Adakah dan seberapa besar pengaruh motivasi belajar dan kesiapan belajar terhadap hasil belajar siswa mata pelajaran sejarah kelas XI IIS di SMA Negeri 1 Prajekan tahun pelajaran 2015/2016?

\section{b. Minor}

1. Adakah dan seberapa besar pengaruh motivasi belajar Intrinsik terhadap hasil belajar siswa mata pelajaran sejarah kelas XI IIS di SMA Negeri 1
Prajekan semester ganjil tahun pelajaran 2015/2016?

2. Adakah dan seberapa besar pengaruh motivasi belajar Ektrinsik terhadap hasil belajar siswa mata pelajaran sejarah kelas XI IIS di SMA Negeri 1 Prajekan semester ganjil tahun pelajaran 2015/2016?

3. Adakah dan seberapa besar pengaruh kesiapan belajar terhadap hasil belajar siswa mata pelajaran sejarah kelas XI IIS di SMA Negeri 1 Prajekan semester ganjil tahun pelajaran $2015 / 2016$ ?

\section{METODE PENELITIAN}

\section{Lokasi dan Waktu Penelitian}

Dari pendapat di atas dapat disimpulkan bahwa dalam penelitian ini untuk menentukan daerah penelitian menggunakan metode "Purposive Sampling Area" yaitu di SMA Negeri 1 Prajekan Kabupaten Bondowoso. Hal ini dikarenakan pihak sekolah memberikan ijin sekolahnya diteliti, peneliti juga didukung oleh guru pamong untuk melakukan penelitian yang berhubungan dengan mata pelajarannya, dan tempatnya terjangkau oleh peneliti.

\section{Desain Penelitian}

Dalam penelitian ini menggunakan pendekatan kuantitatif dan metode rancangan penelitian yang digunakan adalah rancangan Ex Post Facto.

\section{Populasi}

Populasi adalah wilayah generalisasi yang terdiri atas: obyek/subyek yang mempunyai kualitas dan karakteristik tertentu yang ditetapkan oleh peneliti untuk dipelajari dan kemudian ditarik kesimpulannya (Sugiyono, 2013). Populasi dalam penelitian ini adalah seluruh siswa kelas VII SMP Negeri 1 Cermee yang berjumlah 127 orang siswa.

\section{Sampel}

Sampel merupakan bagian dari populasi yang memiliki ciri-ciri atau keadaan tertentu yang akan diteliti. Atau sampel dapat 
didefinisikan sebagai anggota populasi yang dipilih dengan menggunakan prosedur tertentu sehingga diharapkan mewakili populasi. Sampel yang digunakan dalam penelitian ini adalah Simple Random Sampling, merupakan teknik pengambilan sampel yang dilakukan secara acak tanpa memperhatikan strata yang ada dalam populasi tersebut.

\section{Pengumpulan Data}

\section{Tes}

Untuk mengetahui kemampuan siswa dalam memahami dan menguasai materi sebagai tolak ukur ketuntasan belajar siswa.

\section{Observasi}

Semua kegiatan yang ditujukan untuk mengenali, merekam, mendokumentasikan setiap indikator dari proses dan hasil yang dicapai yang ditimbulkan tindakan terencana.

\section{Dokumentasi}

Untuk mencari data mengenai hal-hal berupa catatan, transkrip buku, informasi sekolah dan data sekolah.

\section{Teknik Analisis Data}

Dalam menganalisa data-data hasil penelitian, peneliti akan menguji dengan menggunakan metode statistik, karena data yang diperoleh berupa angka-angka. Pengertian statistik menurut Sugiono (2013:12) dalam arti sempit adalah "Data" tetapi dalam arti luas dapat diartikan "Alat" alat untuk analisis, dan data untuk membuat keputusan.

\section{a. Analisa Regresi}

Persamaan garis regresi persamaan ini digunakan untuk menggambarkan pengaruh prediktor pengaruh penguatan terhadap kriterium berpikir kritis siswa, rumus untuk mencari persamaan garis regresi adalah :

Persamaan garis regresi tiga prediktor

$$
Y=a_{1} x_{1}+a_{2} x_{2}+a_{3} x_{3}+K
$$

\section{b. Menghitung Korelasi}

Korelasi antara kriterium y dengan prediktor $\mathrm{x}_{1}$ dan $\mathrm{x}_{2}$. Statistik ini akan menunjukkan kepada kita apakah garis regresi yang persamaannya telah kita temukan itu cukup efektif untuk memprediksi kriterium y berdasarkan prediktor yang kita pakai rumus perhitungannya adalah sebagai berikut :

$\operatorname{Ry}(1,2,3) \sqrt{\frac{a 1 \sum x 1 y+a 2 \sum x 2+\mathrm{a} 3 \sum x 3 y}{\sum y 2}}$

Keterangan :

Ry $(\mathbf{1 , 2 , 3 )}$ : Koefisien korelasi antara y dengan $\mathrm{x}_{1}$ dan $\mathrm{x}_{2}$

$\mathbf{a}_{1}$ : Koefisien prediktor $\mathrm{x}_{1}$

$\mathbf{a}_{2}$ : Koefision Prediktor $\mathrm{x}_{2}$

$\mathbf{a}_{3}$ : Koefision Prediktor $\mathrm{x}_{3}$

$\mathbf{x}_{1} \mathbf{y}$ : Jumlah produk antara $\mathrm{x}_{1}$ dan $\mathrm{x}_{2}$

$\mathbf{x}_{2} \mathbf{y}$ : Jumlah antara $x_{2}$ dengan $x_{3}$

$\mathbf{x}_{3} \mathbf{y}$ : Jumlah antara $x_{3}$ dengan $y$

$\mathbf{y}^{\mathbf{2}}$ : Jumlah kuadrat kriterium y

\section{c. Menghitung Analisis Varian Garis Regresi}

Untuk mengetahui apakah Ry $(1,2,3)$ signifikan atau tidak harus dilakukan analisis varian garis regresi dengan mencari Freg.

Freg $=\frac{\mathrm{R}^{2}(n-m-1) x^{2}}{\mathrm{~m}\left(1-\mathrm{R}^{2}\right)}$

\section{Keterangan :}

Freg : Harga F garis regresi

$\mathbf{N}$ : Banyaknya data

m : Jumlah prediktor

R : Koefisien korelasi / Ry $(1,2,3)$ dikuadratkan

\section{d. Efektifitas Garis Regresi}

EGR digunakan jika peneliti ingin informasi mengenai sumbangan relatif tiap prediktor dari keseluruhan dengan rumus :

EGR $=\frac{\text { JKreg }}{\text { JKtot }} \times 100 \%$


Yang mana,

$$
\text { Jktot }=\Sigma \mathbf{Y}^{2}
$$

\section{e. Sumbangan Efektif (SE)}

Sumbangan efektif adalah sumbangan prediktor yang dihitung dari keseluruhan efektifitas regresi hal ini peneliti ingin mengetahui sumbangan efektifitas tiap prediktor dari keseluruhan prediksi, maka SE\% tiap prediktor harus dihitung dari presentase efektifitas garis regresi yaitu :

$\mathrm{SE}_{1} \%=\frac{\mathrm{a}_{1} \sum \mathrm{x}_{1} \mathrm{y}}{\mathrm{JKreg}} \times \mathrm{EGR}$
$\mathrm{SE}_{2} \%=\frac{\mathrm{A}_{2} \sum \mathrm{x}_{2} \mathrm{y}}{\mathrm{JKreg}} \times \mathrm{EGR}$
$\mathrm{SE}_{3} \%=\frac{\mathrm{A}_{3} \sum \mathrm{x}_{3} \mathrm{y}}{\mathrm{JKreg}} \times$ EGR

\section{HASIL PENELITIAN}

Dari hasil penelitian yang diperoleh dengan menggunakan rumus analisis variansi garis regresi menghasilkan empiric sebesar 0,60017. Yang apabila dikonsultasikan dengan $\mathrm{r}$ tabel dengan $N$ sebanyak 65 responden dan taraf signifikansi $5 \%$ diperoleh 0,195 . perhitungan tersebut dimaksudkan untuk membuktikan hipotesa kerja mayor dengan menggukan uji signifikansi.

Dari hasil perhitungan analisis variansi garis regresi diperoleh $F$ reg sebesar 14,241. Dan apabila dikonsultasikan dengan $\mathrm{F}$ tabel untuk $\mathrm{db}=3 \mathrm{dan} \mathrm{db}=65$ dengan taraf signifikansi $5 \%$ diperoleh 2,755 Dengan demikian dari hasil perhitungan tersebut menunjukkan $\mathrm{F}$ reg lebih besar dari F tabel.

Berdasarkan hasil analisa data, maka hipotesa kerja mayor yang berbunyi "Ada pengaruh positif antara motivasi belajar dan kesiapan belajar terhadap hasil belajar siswa pada pelajaran sejarah kelas XI IIS di SMA Negeri 1 Prajekan semester ganjil tahun pelajaran 2015/2016" diterima.
Selanjutnya dalam efektifitas garis regresi dipreroleh sebesar 41,189\%. Ini berarti sumbangan efektif dari keseluruhan prediktor hasil belajar siswa memberikan sumbangan sebesar 41,189\% sedangkan prediktor lain yang tidak diteliti memberikan sumbangan sebesar 58,811\%.

Sumbangan Efektif (SE) prediktor $\left(\mathrm{X}_{1}\right)$ motivasi intrinsik terhadap kriterium (Y) hasil belajar siswa 9,381\%, Sumbangan Efektif (SE) prediktor $\left(\mathrm{X}_{2}\right)$ motivasi ekstrinsik terhadap kriterium (Y) hasil belajar siswa $0,830 \%$, Sumbangan Efektif (SE) prediktor $\left(\mathrm{X}_{3}\right)$ kesiapan belajar siswa terhadap kriterium (Y) hasil belajar siswa 30,978\% ini menunjukan bahwa kesiapan belajar siswa lebih berpengaruh terhadap hasil belajar siswa dibanding motivasi belajar.

Dengan melihat hasil data yang telah dipaparkan sebelumnya, maka dapat disimpulkan bahwa "Ada pengaruh positif antara motivasi belajar dan kesiapan belajar terhadap hasil belajar siswa pada pelajaran sejarah kelas XI IIS di SMA Negeri 1 Prajekan semester ganjil tahun pelajaran 2015/2016".

Untuk lebih jelasnya kesimpulan hasil perhitungan dapat dilihat pada tabel berikut :

Tabel Rekapitulasi Hasil Analisa Data

\begin{tabular}{|c|c|r|}
\hline Variabel & EGR & SE \\
\hline $\mathrm{X}_{1}$ & & $9,38 \%$ \\
$\mathrm{X}_{2}$ & & $0,83 \%$ \\
$\mathrm{X}_{3}$ & $30,98 \%$ \\
\hline Jumlah & $41,19 \%$ & $41,19 \%$ \\
\hline $\begin{array}{c}\text { Variabel bebas } \\
\text { lainnya yang } \\
\text { tidak diteliti }\end{array}$ & $58,81 \%$ & $58,81 \%$ \\
\hline Jumlah & $100 \%$ & $100 \%$ \\
\hline
\end{tabular}

Dengan demikian dapat dikatakan bahwa siswa akan semakin meningkat hasil belajarnya apabila didukung oleh motivasi belajar dan kesiapan belajar yang baik selama proses kegiatan pembelajaran. 


\section{KESIMPULAN}

Berdasarkan hasil penelitian dan pembahasannya, peneliti dapat mengambil kesimpulan sebagai berikut:

1. Berdasarkan analisis deskriptif, antara motivasi intrinsik, motivasi ekstrinsik, kesiapan belajar serta hasil belajar menunjukkan bahwa semuanya telah mencapai kategori baik dan cukup baik.

2. Berdasarkan hasil perhitungan uji $F$, Dengan diperoleh nilai $F$ hitung sebesar 14,241 lebih besar dari $F$ tabel 2,75 dengan probabilitas sebesar $0,000<$ 0,05 . hal ini berarti Ada pengaruh kuat yang signifikan motivasi intrinsik, motivasi ektrinsik dan kesiapan belajar terhadap hasil belajar siswa kelas XI IIS di SMA Negeri 1 Prajekan tahun pelajaran 2015/2016.

3. Berdasarkan hasil perhitungan analisa regresi linier ganda, diperoleh koefisien determinasi $\mathrm{R}$ sqr adalah 0,41189 berarti variabel yang dipilih pada variabel independen (motivasi intrinsik, motivasi ektrinsik dan kesiapan belajar) dapat menerangkan variasi variabel dependen (hasil belajar siswa) dengan kontribusi $41,189 \%$, sedangkan sisanya $58,811 \%$ diterangkan oleh variabel lain.

4. Secara parsial, kesiapan belajar memberikan sumbangan terhadap hasil belajar paling besar dibandingkan dengan motivasi intrinsik dan motivasi ekstrinsik. Secara parsial sumbangan dari motivasi intrinsik sebesar 9,381\%, motivasi ekstrinsik sebesar $0,830 \%$, dan $30,978 \%$ untuk kesiapan belajar sekolah.

\section{DAFTAR PUSTAKA}

Arikunto, S. 2011. Prosedur Penelitian: Suatu Pendekatan Praktek. Jakarta: Rineka Cipta.

Darsono, M. 2010. Belajar dan Pembelajaran. Semarang: IKIP Semarang Press

Djamarah, S.B. 2009. Psikologi Belajar. Jakarta: Rineka Cipta.
Hadi, S. 2009. Metodologi Research. Yogyakarta: Andi

Hamalik. 2009. Kurikulum dan Pembelajaran. Jakarta: Bumi Aksara

Kartini, Kartono. 2009. Pengantar Metodologi Riset Sosial. Bandung: Mandar Maju.

Mudjiono. 2010. Belajar dan Pembelajarn. Jakarta: Rineka Cipta.

Nasution. 2003. Berbagai Pendekatan dalam Proses Belajar dan Mengajar. Jakarta: Bumi Aksara.

Nazir, M. 2009, Metode Penelitian. Bogor: Ghalia Indonesia.

Nurseto. T. 2010. Pembelajara Motivasi Berprestasi Dalam Mata Kuliah Kewirausahaan. Jurnal Ekonomi \& Pendidikan. VII. 01. 82-93

Poerwadarminta, W.J.S. 2010. Kamus Umum Bahasa Indonesia. Jakarta: Balai Pustaka.

Riyanto, Y. 2010. Metodologi Penelitian Pendidikan, Surabaya: Penerbit SIC

Sardiman. 2011. Interaksi dan Motivasi Belajar Mengajar. Jakarta: PT. Raja Grafindo Persada

Slameto. 2012. Belajar dan Faktor-Faktor Yang Mempengaruhi. Jakarta: Rineka Cipta.

Soemanto. 2010 Psikologi Pendidikan. Jakarta: Rineka Cipta.

Sudjana, N. 2001. Penilaian Hasil Proses Belajar Mengajar. Bandung: Remaja Rosdakarya.

Sugiyono. 2013. Metode Penelitian Pendidikan; Pendekatan Kuantitatif, Kualitatif, $R \& D$. Bandung: Alfabeta.

Suryabrata, S. 2012. Psikologi Pendidikan. Jakarta: PT. Grafindo Perkasa

Sutikno, M.S. 2012. Menuju Pendidikan Bermutu. Mataram: NTP Press

Syah, M. 2010. Psikologi Pendidikan dengan Pendekatan Baru. Bandung: Remaja Rosdakarya

Walgito, B. 2010. Pengantar Psikologi Umum. Yogyakarta: Penerbit Andi. 